\title{
Sri Lanka
}

National Cancer Institute

\section{Source}

National Cancer Institute. SriLanka. NCI Thesaurus. Code C17163.

A country in southern Asia, occupying an island in the Indian Ocean, southeast of India. 